\title{
Pregnancy loss during the embryonic period
}

\author{
Dale Paccamonti and Elaine Carnevale ${ }^{2}$ \\ Department of Veterinary Clinical Sciences, School of Veterinary Medicine, Louisiana State University, Baton Rouge ${ }^{1}$ and Equine Reproduction Laboratory, Colo- \\ rado State University, Fort Collins, $\mathrm{CO}^{2}$
}

\begin{abstract}
Summary
Demise of the conceptus before organogenesis is complete, (approx. $40 \mathrm{~d}$ gestation in mares), is termed early embryonic death (EED). Many factors affect embryo viability. Genetic abnormalities, defective gametes, factors affecting conceptus mobility, asynchrony between the embryo and the uterus, endometritis, nutritional stress, twins and premature regression of the corpus luteum due to uterine pathology or other inflammatory conditions are among the causes of EED. Diagnosis, sometimes aided by laboratory tests, is primarily by ultrasonographic examination. Prevention of EED includes reducing contamination at breeding and treating endometritis to allow establishment of pregnancy. Correction of anatomic defects is necessary. If exogenous progestogen therapy is used, the viability of the pregnancy should be periodically reaffirmed. The present paper reviews the causes and diagnosis of EED in mares, as well as therapeutic and preventative measures to reduce the incidence of EED.
\end{abstract}

Keywords: embryonic death, mare, embryo, pregnancy loss, infertility

\section{Trächtigkeitsverlust während der embryonalen Periode}

Der Verlust des Konzeptus vor Abschluss der Organogenese (bei der Stute ca. am 40. Gestationstag) wird als früher Embryonaltod (early embryonic death - EED) bezeichnet. Die embryonale Lebensfähigkeit wird von zahlreichen Faktoren beeinflusst: so spielen genetische Abnormalitäten, defekte Gameten, die Mobilität des Konzeptus beeinflussende Fakłoren, Störungen in der Interaktion zwischen Embryo und Uterus, Endometritiden, fütterungsbedingter Stress, Zwillingsträchtigkeiten sowie eine vorzeitige luteale Regression aufgrund uteriner Veränderungen oder anderweitiger entzündlicher Vorgänge eine wichtige Rolle in der Entstehung von EED. Die Diagnose wird primär durch ultrasonographische Untersuchungen gestellt und manchmal durch Laboruntersuchungen ergänzt. Präventive Maßnahmen zur Vermeidung eines EED und Erhaltung der Trächtigkeit beinhalten eine Verminderung der Kontamination im Rahmen der Belegung/Besamung sowie die Behandlung von Endometritiden. Des Weiteren ist eine Behebung anatomischer Defekte nötig. Im Falle einer exogenen Progestagentherapie sollte das Bestehen der Trächtigkeit regelmäßig kontrolliert werden. Die vorliegende Arbeit liefert einen Überblick über Ursachen und die Diagnosestellung der EED bei der Stute, sowie über therapeutische und präventive Maßnahmen zur Reduktion der Inzidenz von EED.

Schlüsselwörter: Embryonaler Tod, Stute, Embryo, Trächtigkeitsverlust, Infertilität, Reproduktion

The embryonic period encompasses the time from fertilization until organogenesis is complete, in horses the first 40 days of gestation. Pregnancy losses are greatest during this period, estimated to be as high as $24 \%$ in mares (as reviewed in Ball 1988). Predicting embryonic loss can be difficult. Progesterone is often measured, but not often useful as a predictive tool. Although continued low progesterone is not compatible with pregnancy, a single low progesterone value does not necessarily indicate impending embryonic loss. Low progesterone concentration at more than one sampling is necessary before a diagnosis of embryonic loss or non-pregnant can be made. Examination by transrectal ultrasonography provides the best means to predict and detect embryonic loss. Embryonic vesicles found to be smaller than expected for their age are considered to be at increased risk, while oversized vesicles are not (Ginther et al. 1985). Embryonic loss may occur between days 11-15 post ovulation without any ultrasonographic indication of its impending occurrence. Later in gestation, however, indications of impending loss may be observed and include a speckled or granular appearance of the conceptus, mobility of the vesicle after the normal time of fixation, fluid surrounding the vesicle, absence of a heartbeat, decreased volume of the conceptus, disruption of conceptus membranes or edema of the endometrial folds (Ginther et al. 1985). If available, Doppler ultrasonography may be useful to assess embryo viability. In a normal pregnancy, blood flow is greater in the uterine arteries of the gravid horn. A relative decrease in flow in the arteries of the gravid horn compared to the nongravid horn is seen during embryonic demise (Chen and Stolla 2006).

Fertilization rates are normally high in horses, although differences may exist between normal and subfertile mares. Although oviductal problems may affect early pregnancy rates, assessment of fertilization and embryonic loss in the oviduct is difficult to assess. Nonetheless, significantly fewer oocytes or embryos were recovered from mares 20 years of age or older than from mares 10 years of age or less, suggesting failure of ovulation or oviductal pickup of the oocyte. Consequently, fewer oocytes had the potential for fertilization and embryo development in the older mares (Carnevale et al. 1993).

In many species, genetic abnormalities play a significant role in pregnancy loss. Chromosomal abnormalities have been identified in normal appearing equine embryos (Rambags et al. 2005) and an increased incidence of embryonic loss has been associated with certain family lines or stallions. Many chromosomal abnormalities may not be inherited but may 
arise during formation and ageing of gametes and result in an inability of the resulting zygote to develop into a viable embryo. Ageing gametes may be increased when mating is not closely timed to ovulation. The incidence of embryonic loss is higher when insemination occurs after ovulation and increases as the interval from ovulation to insemination lengthens (Koskinen et al. 1990). Visible defects in embryos are associated with a reduced potential for normal development. Pregnancy rates at 16 days were significantly higher after transfer of excellent and good embryos than fair/poor embryos. However, the embryo loss rate from days 16 to 50 was similar for good and fair/poor embryos and was higher than for excellent embryos (Carnevale et al. 2000).

A critical period occurs at 14 to 16 days of gestation when the conceptus is needed to inhibit luteolysis. Factors of conceptus origin inhibit the release of PGF from the endometrium and are essential for maintenance of luteal function (Stout and Allen 2002). Unrestricted conceptus mobility is essential for pregnancy maintenance and prevention of luteolysis (Sharp et al. 1989). Anything that interferes with embryonic mobility, such as transluminal adhesions or endometrial cysts, or with uterine contractions, the main propulsive force stimulating embryo movement, may result in embryonic loss. Experimentally, restriction of conceptus mobility has resulted in luteolysis and conceptus loss; however, administration of a progestogen was able to rescue the pregnancy (Sharp et al. 1989).

It is often thought that fertility is dependent primarily on the uterus. Pregnancy rates were similar when embryos from normal and subfertile mares were transferred into normal mares (Douglas 1982), and initial pregnancy rates were similar after transfer of embryos to normal and subfertile recipient mares. However, subsequent embryonic loss was greater for subfertile recipients (Squires et al. 1982). Additional evidence indicates other factors are involved. Transfer of embryos from normal mares to normal and subfertile recipients resulted in similar pregnancy rates, indicating that the uterus of a subfertile mare may be capable of supporting an embryo from a normal mare (Ball et al. 1987). Embryos collected from the oviducts of normal and subfertile donors and transferred to normal recipients resulted in lower pregnancy rates for mares receiving embryos from subfertile donors than for mares receiving embryos from normal donors (Ball et al. 1989).

Extremes of age, either young or old, negatively affect fertility. The high rate of embryonic loss in yearling mares has been attributed to immaturity, inadequate nutrition or physical stress (Mitchell and Allen 1975). Older mares have a lower pregnancy rate and a higher loss rate compared with younger mares (Ball et al. 1989). The effect of advanced age, however, is difficult to separate from acquired subfertility and is confounded by the effect of parity since the two are generally correlated. The effect of age on fertility, at least in part, originates in the oocyte. When embryos were collected from the oviducts of young mares and old mares, significantly fewer cells and poorer morphology was observed in embryos from old mares (Carnevale et al. 1993). In a subsequent study (Carnevale and Ginther 1995), oocyte transfer was used to compare fertility of oocytes from young mares and old mares and more embryonic vesicles resulted from young than old mares.
The repeatability of embryonic loss is equivocal and may depend on the inciting cause. Oviductal pathology may result in either embryonic loss or fertilization failure. Uterine pathology may affect histotrophe production, which the early embryo relies on, and result in retarded embryonic development. Endometrial cysts are common in older mares. The effect of cysts on fertility is unclear, because studies are often confounded by other factors such as age and parity. One study found that cysts did not affect the ability to establish or maintain pregnancy. Still, the time of initial pregnancy exam was not controlled and embryonic losses occurring before pregnancy exams were not detected and the odds ratio of establishing pregnancy was suggestive of a negative effect (Eilts et al. 1995). Other studies have corroborated the quantitative effect of cysts on fertility, and cysts present in sufficient number or size decrease fertility. Although endometrial cysts may interfere with maternal recognition of pregnancy, once pregnancy is established they do not increase the likelihood of pregnancy loss (Eilts et al. 1995).

Progesterone is essential for the maintenance of pregnancy yet little evidence exists to indicate primary luteal insufficiency is a major cause of embryonic loss. Secondary luteal insufficiency, resulting from uterine pathology or unrelated inflammatory conditions, is a more likely cause of embryonic loss (Daels et al. 1989, Stabenfeldt and Hughes 1987). Inflammatory conditions, even soon after ovulation, and especially before endometrial cup formation, warrant attention. PGF inhibitors are effective in blocking PGF release, but must be administered soon after the inciting cause (Daels et al. 1989). Exogenous progestogens can maintain pregnancy even after luteal activity is compromised (Daels et al. 1989), and should be continued until placental progestins are capable of maintaining pregnancy. Supplemental progesterone, however, has not improved pregnancy rates in normal mares receiving embryos (Juliano and Squires 1986).

Endometritis, often the result of a delay in uterine clearance, is an important cause of embryonic loss in mares (Woods et al. 1987) and usually causes loss before maternal recognition of pregnancy. Once pregnancy is established, endometritis is a less frequent cause of embryonic loss (Ricketts 2003), provided anatomical defects are corrected. Embryonic death may result either indirectly as a result of inflammatory mediated prostaglandin release or from a direct embryotoxic effect.

Some specific infectious diseases have been associated with embryonic loss. For example, contagious equine metritis, a transmissible venereal disease caused by Taylorella equigenitalis, commonly results in embryonic loss after initial infection (Timoney and Powell 1988). Both mares and stallions can maintain the organism as inapparent carriers (Timoney and Powell 1988). Control includes identifying carriers, improving hygiene during breeding, using artificial insemination and surgical ablation of the clitoral sinuses (Timoney and Powell 1988).

Although embryonic loss has been attributed to breeding at foal heat, some studies have found that even though pregnancy rates may be lower, no greater losses occur after foalheat breeding than after later breedings (Woods et al. 1987). The presence of intrauterine fluid at foal heat is correlated 
with lower pregnancy rates and a greater risk of embryonic loss (McKinnon et al. 1988).

Nutritional stress, either from malnutrition (van Niekerk 1965) or poor quality protein in the ration (van Niekerk and van Niekerk 1998) has been associated with an increased incidence of pregnancy loss. A good nutritional program is clearly advisable for pregnant mares. Other stresses, such as hauling for long periods, are often suggested as causing embryonic loss. However, controlled studies failed to substantiate this belief (Baucus et al. 1990).

Reducing the incidence of embryonic loss begins with reducing contamination at breeding and treating endometritis to allow establishment of pregnancy. Correction of anatomic defects such as poor perineal conformation with procedures such as Caslick's surgery is necessary. Maintenance of good general health and nutrition is likewise important. Repeated embryonic loss attributable to a failure of maternal recognition of pregnancy can be prevented with supplemental progestogens such as altrenogest. A number of synthetic progestogens, including medroxyprogesterone, norgestomet and megestrol acetate, were unable to maintain pregnancy (McKinnon et al. 2000). To ensure pregnancy maintenance, exogenous progestogen therapy should be continued through the first 4 months of gestation, until the placenta can be considered to provide adequate progestogens for pregnancy support. If the uterine environment is normal, progesterone therapy is probably not needed (Stabenfeldt and Hughes 1987), however, the difficulty lies in determining if the uterine environment is normal from the viewpoint of the conceptus. Viability of a pregnancy should be reaffirmed when long term progestogen therapy is practiced. Retention of a conceptus after fetal death may result from continued treatment.

\section{References}

Ball B. A. (1988) Embryonic loss in mares. Vet. Clin. N. Am. Eq. Prac 4, 263-290

Ball B. A., Hillman R. B. and Woods G. L. (1987) Survival of equine embryos transferred to normal and subfertile mares. Theriogenology 28, 167-174

Ball B. A., Little T. V., Weber J. A. and Woods G. L. (1989) Survival of day-4 embryos from young, normal mares and aged, subfertile mares after transfer to normal recipient mares. J. Reprod. Fert. 85, 187-194

Baucus K. L., Ralston S. L., Nockels C. F., McKinnon A. O. and Squires E. L. (1990) Effects of transportation on early embryonic death in mares. J. Anim. Sci. 68, 345-351

Carnevale E. M. and Ginther O. J. (1995) Defective oocytes as a cause of subfertility in old mares. Biol. Reprod. Mono. 1 Eq. Reprod. VI 209-214

Carnevale E. M., Griffin P. G. and Ginther O. J. (1993) Age-associated subfertility before entry of embryos into the uterus in mares. Equine Vet. J. Suppl. 15, 31-35

Carnevale E. M., Ramirez R. J., Squires E. L., Alvarenga M. A., Vanderwall D. K. and McCue P. M. (2000) Factors affecting pregnancy rates and early embryonic death after equine embryo transfer. Theriogenology 54, 965-979

Chen Y. H. and Stolla R. (2006) Using "Uterine Index" to diagnose embryonic death in mares. J. Eq. Vet. Sci. 26, 219-224

Daels P. F., Stabenfeldt G. H., Kindahl H. and Hughes J. P. (1989) Prostaglandin release and luteolysis associated with physiological and pathological conditions of the reproductive cycle of the mare: a review. Equine Vet. J. Suppl. 8, 29-34
Douglas R. H. (1982) Some aspects of equine embryo transfer. J. Reprod. Fert. Suppl. 32, 405-408

Eilts B. E., Scholl D. T., Paccamonti D. L., Causey R., Klimczak J. C. and Corley J. R. (1995) Prevalence of endometrial cysts and their effect on fertility. Biol. Reprod. Mono. 1 Eq. Reprod. VI, 527-532

Ginther O. J., Bergfelt D. R., Leith G. S. and Scraba S. T. (1985) Embryonic loss in mares: Incidence and ultrasonic morphology. Theriogenology 24, 73-86

Iuliano M. F. and Squires E. L. (1986) Effect of exogenous progesterone on pregnancy rates after surgical embryo transfer in mares. Theriogenology 26, 291-298

Koskinen E., Lindeberg H., Kuntsi H., Ruotsalainen L. and Katila T. (1990) Fertility of mares after postovulatory insemination. Zentralbl. Veterinarmed. A 37, 77-80

McKinnon A. O., Lescun T. B., Walker J. H., Vasey J. R. and Allen W. R. (2000) The inability of some synthetic progestagens to maintain pregnancy in the mare. Equine Vet. J. 32, 83-85

McKinnon A. O., Squires E. L., Harrison L. A., Blach E. L. and Shideler R. K. (1988) Ultrasonographic studies on the reproductive tract of mares after parturition: Effect of involution and uterine fluid on pregnancy rates in mares with normal and delayed first post partum ovulatory cycles. J. Am. Vet. Med. Assoc. 192, 350 353

Mitchell D. and Allen W. R. (1975) Observations on reproductive performance in the yearling mare. J. Reprod. Fert. Suppl. 23, 531 536

Rambags B. P. B., Krijtenburg P. J., VanDrie H. F., Lazzari G., Galli C., Pearson P. L., Colenbrander B. and Stout T. A. E. (2005) Numerical chromosomal abnormalities in equine embryos produced in vivo and in vitro. Mol. Reprod. Dev. 72, 77-87

Ricketts S. W. (2003) Early pregnancy failure as seen during the course of equine stud farm practice in Newmarket, 1996-2003. Pferdeheilkunde 19, 633-638

Sharp D. C., McDowell K. J., Weithenaver J. and Thatcher W. W. (1989) The continuum of events leading to maternal recognition of pregnancy in mares. J. Reprod. Fert. Suppl. 37, 101-107

Squires E. L., Imel K. J., Iuliano M. F. and Shideler R. K. (1982) Factors affecting reproductive efficiency in an equine embryo transfer programme. J. Reprod. Fert. Suppl. 32, 409-414

Stabenfeldt G. H. and Hughes J. P. (1987) Clinical aspects of reproductive endocrinology in the horse. Comp. Cont. Educ. Prac. Vet. 9, 678-684

Stout T. A. E. and Allen W. R. (2002) Prostaglandin E-2 and F-2 alpha production by equine conceptuses and concentrations in conceptus fluids and uterine flushings recovered from early pregnant and dioestrous mares. Reproduction 123, 261-268

Timoney P. J. and Powell D. G. (1988) Contagious equine metritis epidemiology and control. J. Eq. Vet. Sci. 8, 42-46

van Niekerk C. H. (1965) Early embryonic resorption in mares. J. S. Afr. Vet. Med. Assoc. 36, 61-69

van Niekerk F. E. and van Niekerk C. H. (1998) The effect of dietary protein on reproduction in the mare. VII. Embryonic development, early embryonic death, foetal losses and their relationship with serum progestagen. J. S. Afr. Vet. Med. Assoc. 69, 150-155

Woods G. L., Baker C. B., Baldwin J. L., Ball B. A., Bilinski J., Cooper W. L., Ley W. B., Mank E. C. and Erb H. N. (1987) Early pregnancy loss in brood mares. J. Reprod. Fert. Suppl. 35, 455459

Dale Paccamonti, DVM, MS, Dip ACT

Department of Veterinary Clinical Sciences

School of Veterinary Medicine

Lovisiana State University

Baton Rouge, LA 70803

pacc@lsu.edu 